\title{
PENGARUH MODEL PEMBELAJARAN KOOPERATIF TIPE MAKE A MATCH TERHADAP HASIL BELAJAR MATEMATIKA SISWA KELAS V SD NEGERI 060915 JL TB SIMATUPANG KECAMATAN MEDAN SUNGGAL TAHUN PEMBELAJARAN 2018/2019
}

WENY GLORY HIDAYATI HALAWA (PGSD FKIP UNIVERSITAS KATOLIK SANTO THOMAS)

\begin{abstract}
The purpose of this research is to know the effect of make amatch type learning to student learning outcome in mathematics in subject at the fifth grade student of SD 060915. The method of this research was a quasi-experimental research with pretest posttest control group design. The experiment sample was 30 students that used make amatch cooperative learning method. The control sample was 30 students that used speech method. The instruments of this research wasobjective learning outcomes test with 15 questions. The technique of analysis data was t-test. Based on the calculation, $\mathrm{t}$-score showed that $\mathrm{t}$-count was 2,127 and $\mathrm{t}$-table was 1,672 at the significance level of $5 \%$ which means $\mathrm{t}$-count $>\mathrm{t}$ table $(2,127>1,672)$, so Ho was rejected and Ha was accepted. It can be concluded that cooperative learning make a match type has positive influence to student learning outcome in mathematics in subject at the fifth grade student of SD 060915 in addition and subtraction of ordinary fragment and mixed fragment concept.
\end{abstract}

Keywords:cooperative learning type make a match, learning outcomes

\section{PENDAHULUAN}

\section{Latar Belakang Masalah}

Pendidikan memegang peranan sangat penting dalam menciptakan siswa yang berprestasi dan memiliki kualitas sumber daya manusia (SDM) yang berkualitas dan berdaya guna bagi masyarakat.Peningkatan sumber daya manusia merupakan langkah terpenting yang harus ditempuh dalam dunia pendidikan. Sumber daya manusia yang berkualitas dan berpotensi dalam arti yang luas yang diciptakan oleh dunia pendidikan akan membentuk sumber daya manusia tersebut dalam rangka menyikapi perubahan global yang akan mempengaruhi tata kehidupan bermasyarakat, berbangsa dan bernegara.

Undang-undang RI No. 20 Tahun 2003, Bab 1 Pasal 1 tentang Sistem Pendidikan Nasional (Sisdiknas) yang menjelaskan bahwa pendidikan adalah usaha sadar dan terencana untuk mewujudkan suasana belajar dan proses pembelajaran agar peserta didik secara aktif mengembangkan potensi dirinya 
untuk memiliki kekuatan spiritual keagamaan, pengendalian diri, kepribadian, kecerdasan, akhlak mulia, serta keterampilan yang diperlukan dirinya, masyarakat, bangsa dan negara.

Berdasarkan Undang-undang tersebut, maka pendidikan bertujuan untuk mewujudkan suasana belajar dan proses pembelajaran aktif agar siswa dapat mengembangkan potensi yang dimilikinya. Dalammewujudkan suasana belajar dan pembelajaran aktif diharapkan adanya sebuah interaksi edukatif yakni terjadinya proses kegiatan belajar mengajar antara seorang guru dan peserta didik. Proses belajar mengajar yang terjadi didalam kelas tidak lepas dari adanya peran seorang guru. Guru merupakan salah satu komponen manusia dalam proses belajar mengajar, yang bertugas dan bertanggungjawab dalam usaha pembentukan sumber daya manusia yang berkualitas.

Dalam membentuk manusia yang berkualitas diperlukan guru yang berkualitas, artinya guru dituntut harus memiliki berbagai kompetensi atau kemampuan sesuai dengan tuntutan masyarakat yang semakin berkembang karena keberhasilan pendidikan tidak terlepas dari kompetensi atau kemampuan guru khususnya guru SD yang merupakan ujung tombak dalam pendidikan dasar. Oleh karena itu guru SD harus menguasai berbagai kompetensi keguruan antara lain kompetensi pedagogik yaitu kemampuan mengajar, dimana guru harus mampu menciptakan lingkungan belajar yang efektif dan menyenangkan serta mampu mengolah kelasnya, kompetensi sosial berarti guru mampu berkomunikasi dan berinteraksi secara efektif dan efesien didalam dan di luar lingkungan sekolah, kompetensi kepribadian berarti guru dapat diteladani atau dicontoh melalui sikap dan tingkah lakunya, dan kompetensi profesional berarti guru mampu menguasai materi pelajaran secara luas dan mendalam. Dikatakan guru profesional apabila sudah memiliki dan mengusai keempat kompetensi keguruan dalam mengajar.

Guru profesional mampu menggunakan model pembelajaran yang berorientasi pada peningkatan intensitas keterlibatan siswa secara efektif didalam proses pembelajaran. Penggunaan modelpembelajaran yang tepatbertujuan untukmemungkinkan siswa dapat belajar secara aktif dan menyenangkan sehingga siswa dapat meraih hasil belajar yang optimal.Salah satu indikator tercapai atau 
tidaknya suatu proses pembelajaran adalah dengan melihat hasil belajar yang telah dicapai oleh siswa. Hasil belajar dipengaruhi oleh banyak faktor salah satunya adalah pemahaman peserta didik terhadap materi yang disampaikan oleh guru. Jika hasil belajar terukur secara efektif dan efesien serta pembelajaran menarik dan menyenangkan bagi peserta didik, maka kondisi belajar dan pengelolaan belajar pasti akan berjalan dengan baik.

Untuk mencapai hasil belajar yang baik dalam pembelajaran maka guru dituntut untuk selalu berusaha meningkatkan profesionalismenya dalam memahami dan menyampaikan bahan atau materi pelajaran kepada siswanya. Adapun mata pelajaran yang dipelajari di SD/ MI antara lain, Ilmu Pengetahuan Alam (IPA), IlmuPengetahuan Sosial (IPS), matematika, pendidikan kewarganegaraan, seni budaya, bahasa Indonesia, dari mata pelajaran yang diajarkan, penelitian ini terfokus pada mata pelajaran Matematika.

Matematika merupakan salah satu pelajaran yang tidak dapat dipisahkan dari dunia pendidikan dan mempunyai peranan yang sangat penting dalam mencetak SDM yang berkualitas diera kemajuan ilmu pengetahuan dan teknologi. Karena itu pendidikan matematika perlu dibekalkan kepada setiap peserta didik mulai SD, bahkan sejak TK. Pelajaran matematika adalah suatu sarana untuk mengembangkan cara berpikir siswa. Hal ini dikarenakan matematika adalah ilmu yang berhubungan dengan penalaran dan pola pikir manusia.Melalui pendidikan matematika diharapkan siswa dapat terampilmemecahkan masalah dalam kehidupan sehari-harinya.

Namun, kenyataan yang terjadi dilapangan yaitu masih banyak siswa yang menganggap bahwa pelajaran matematika adalah mata pelajaran yang sulit.Hal ini dikarenakan dalam proses pembelajaran matematika siswa terlibat hanya sebatas mengerjakan soal-soal perhitungan baik penjumlahan, pengurangan, perkalian dan pembagian yang diberikan guru sehingga siswa cenderung malas dan tidak termotivasi dalam pembelajaran matematika. Selain itu guru masih belum menggunakan model pembelajaran yang bervariasi dalam pembelajaran matematika, siswa hanya menerima penjelasan dari guru dan proses pelaksanaannya masihdidominasi oleh guru (teacher centered). 
Berdasarkan hasil observasi dimana peneliti melihat dan mengamati keadaan siswa kelas V SD Negeri 060915 J1. TB Simatupang Kecamatan Medan Sunggal ketika sedang belajar matematika didalam kelas, banyak siswa yang kurang memperhatikan penjelasan guru seperti ada siswa yang berbicara dengan teman sebangkunya, ada yang kelihatan mengantuk, bahkan ada siswa yang hanya melamun saat guru menerangkan materi. Hal ini juga didukung dengan informasiyang diperoleh dari wali kelas $\mathrm{V}$, beliau mengatakan siswanya sering tidak mengerjakan tugas dengan alasan tidak mengerti walaupun sudah dijelaskan secara berulang.Beliau juga mengatakan ketika diadakan ulangan harian masih banyak siswa yang mendapatkan nilai dibawah KKM.Berikut hasil belajar siswa kelas VA dan VB pada mata pelajaran matematika:

\section{Nilai Ulangan Matematika Materi Pecahan Semester Genap Siswa Kelas V}

\begin{tabular}{|l|c|c|c|c|c|c|}
\hline Kelas & KKM & $\begin{array}{c}\text { Jumlah } \\
\text { Siswa }\end{array}$ & $\begin{array}{c}\text { Siswa } \\
\text { Tuntas }\end{array}$ & $\begin{array}{c}\text { Siswa } \\
\text { Tidak } \\
\text { Tuntas }\end{array}$ & $\begin{array}{c}\text { Presentase } \\
\text { Siswa Tuntas } \\
(\%)\end{array}$ & $\begin{array}{c}\text { Presentase } \\
\text { Siswa } \\
\text { Belum } \\
\text { Tuntas (\%) }\end{array}$ \\
\hline VA & 65 & 36 & 15 & 21 & $42 \%$ & $58 \%$ \\
\hline VB & 65 & 33 & 18 & 15 & $55 \%$ & $45 \%$ \\
\hline
\end{tabular}

(Sumber: Wali Kelas V)

Berdasarkan tabel diketahui bahwa persentase ketuntasan hasil belajar matematika kelas V masih rendah. Ketuntasan kelas VAyaitu 42\% dari 15 siswa dan kelas VByaitu 55\% dari 18 siswa.

Proses pembelajaran matematika yang lebih baik dan bermutu disekolah adalah suatu keharusan yang tidak dapat ditawar lagi. Oleh karena itu, dalam meningkatkan pemahaman dan hasil belajar siswa dalam mata pelajaran matematika pada jenjang sekolah dasar dapat menggunakan model pembelajaran kooperatif yang tepat.Peneliti memilih salah satu tipe pembelajaran yang tepat, menarik, menyenangkan bagi siswa, dan dapat digunakan dalam mengatasi masalah yang telah diungkapkan diatas yaitu model pembelajaran kooperatif tipe make a match.

Model pembelajaran kooperatif tipemake a match (membuat pasangan) merupakan salah satu jenis dari model pembelajaran kooperatif. Penerapan model ini dimulai dengan teknik, yaitu siswa disuruh mencari pasangan kartu yang 
merupakan jawaban atau soal sebelum batas waktunya, siswa yang dapat mencocokan kartunya diberi poin (Rusman, 2017: 223). Hal-hal yang perlu dipersiapkan jika pembelajaran dikembangkan dengan model pembelajaran kooperatif tipe make a match adalah kartu-kartu. Kartu-kartu tersebut terdiri dari kartu-kartu berisi pertanyaan-pertanyaan dan kartu lainnya berisi jawaban dari pertanyaan-pertanyaan tersebut.Melalui model pembelajaran kooperatif tipe make a match ini tentu akan sangat membantu siswa untuk mengembangkan kemampuan berpikirnya. Dengan kemampuan berpikir yang tinggi diharapkan hasil belajar siswa dalam bidang matematika akan semakin meningkat.

Pemilihan model pembelajaran kooperatif tipe make a matchdalam penelitian eksperimen iniberdasarkan penelitian eksperimen oleh Feti Riantika 2016 yang berjudul "Pengaruh Model Cooperative Learning Tipe Make a Match Terhadap Hasil Belajar Matematika Siswa Kelas V SDN 2 Metro Selatan”. Berdasarkan penelitian ini diperoleh rata-rata kelas eksperimen yaitu kelas yang diberikan perlakuan model make a match adalah 74,25. Sedangkan kelas kontrol yaitu kelas yang tidak diberikan perlakuan, rata-ratanya adalah 71,14 . Hal tersebut didukung dengan hasil perhitungan $t_{\text {hitung }}>t_{\text {tabel }}$, yaitu $0,037>0,050$. Dari penelitian tersebut dapat disimpulkan bahwa model cooperative learning tipe make amatch berpengaruh lebih baik terhadap hasil belajar siswa.

Berdasarkan latar belakang masalah di atas, penulis bermaksud mengadakan penelitian mengenai Pengaruh Model Pembelajaran KoperatifTipe Make A Match Terhadap Hasil Belajar Matematika Siswa Kelas V SD Negeri 060915 Jl. TB Simatupang Kecamatan Medan Sunggal Tahun Pembelajaran 2018/2019.

\section{Identifikasi Masalah}

Berdasarkan latar belakang yang dikemukan diatas, masalah-masalah dalam penelitian ini dapat diidentifikasi sebagai berikut:

1. Siswa masih menganggap pelajaran matematika sulit.

2. Hasil belajar matematika masih rendah.

3. Pembelajaran masih cenderung teacher centered (berpusat pada guru).

4. Kondisi pembelajaran masih kurang kondusif. 


\section{Batasan Masalah}

Berdasarkan identifikasi masalah di atas, peneliti membatasi masalah yang diteliti, yaknipengaruh model pembelajaran kooperatif tipe make amatchterhadap hasil belajar matematika pada materi penjumlahan dan pengurangan pecahan biasa dan campuransiswa kelas V SD Negeri 061915 Jl. TB Simatupang Kecamatan Medan Sunggal Tahun Pembelajaran 2018/2019.

\section{Perumusan Masalah}

Berdasarkan latar belakang yang telah diuraikan diatas, peneliti merumuskan beberapa permasalahan. Adapun rumusan masalah yang dikaji adalah sebagai berikut:

1. Bagaimana hasil belajar matematika siswa kelas eksperimen sebelum dan sesudah menggunakan model pembelajaran kooperatif tipe make a match tahun pembelajaran 2018/2019?

2. Bagaimana hasil belajar matematika siswa kelas kontrol sebelum dan sesudah pembelajaran tanpa menggunakan model pembelajaran kooperatif tipe make a match tahun pembelajaran 2018/2019?

3. Adakah pengaruh yang signifikan dalam penerapan model pembelajaran kooperatif tipe make a match terhadap hasil belajar matematikasiswa kelas V SD Negeri 060915 Jl. TB Simatupang Kecamatan Medan Sunggal tahun pembelajaran 2018/2019.

\section{Tujuan Penelitian}

Berdasarkan rumusan masalah diatas, yang menjadi tujuan penelitian ini adalah sebagai berikut:

1. Untuk mengetahui hasil belajar matematika siswa kelas eksperimen sebelum dan sesudah menggunakan model pembelajaran kooperatif tipe make a match tahun pembelajaran 2018/2019?

2. Untuk mengetahui hasil belajar matematika siswa kelas kontrol sebelum dan sesudah pembelajaran tanpa menggunakan model pembelajaran kooperatif tipe make a match tahun pembelajaran 2018/2019? 
3. Untuk mengetahui adakah pengaruh yang signifikan dalam penerapan model pembelajaran kooperatif tipe make a match terhadap hasil belajar matematika siswa kelas V SD Negeri 060915 Jl. TB Simatupang Kecamatan Medan Sunggal tahun pembelajaran 2018/2019.

\section{Manfaat Penelitian}

Manfaat yang diharapkan dalam kaitannya dengan penelitian ini adalah sebagai berikut:

1. Manfaat Teoritis

Diharapkan penelitian ini dapat memberikan sumbangan wawasan dan pengetahuan tentang penggunaan model pembelajaran kooperatif tipe make a match dalam pembelajaran matematika bagi calon guru yang akan memasuki dunia pendidikan.

2. Manfaat Praktis

a) Bagi Guru

Sebagai alternatif model pembelajaran yang dapat digunakan untuk memudahkan guru dalam mencapai tujuan pembelajaran sehingga dapat meningkatkan hasil belajar.

b) Bagi Sekolah

Memberikan sumbangan pemikiran dalam upaya mengadakan perbaikanperbaikan untuk meningkatkan mutu proses dan hasil belajar siswa.

c)Bagi Peneliti Selanjutnya

Hasil penelitian dapat dijadikan sebagai acuan untuk menambah pengetahuan dan wawasan bagi rekan peneliti lain dalam penelitian selanjutnya yang mengambil topik yang sama yaitu tentang pengaruh model pembelajaran kooperatif tipe make a match pada mata pelajaran matematika.

\section{METODOLOGI PENELITIAN}

\section{Pendekatan dan Metode Penelitian}

Penelitian yang dilakukan oleh peneliti adalah penelitian eksperimen. Noor (2015: 112) menjelaskan penelitian eksperimen adalah suatu rancangan percobaan dengan setiap langkah tindakan yang terdefenisikan, sehingga informasi yang berhubungan dengan atau diperlukan untuk persoalan yang akan 
diteliti dapat dikumpulkan secara faktual. Sugiyono (2016: 72) menjelaskan bahwa penelitian eksperimen dapat diartikan sebagai metode penelitian yang digunakan untuk mencari pengaruh perlakuan tertentu terhadap yang lain dalam kondisi yang terkendalikan.

Pendekatan yang digunakan dalam penelitian ini adalah pendekatan kuantitatif.Sugiyono (2016: 7-8) menjelaskan bahwa pendekatan kuantitatif merupakan pendekatan ilmiah yang digunakan untuk meneliti populasi atau sampel tertentu yang berlandaskan filsafat positivisme, yaitu filsafat yang memandang suatu realitas/gejala/fenomena itu dapat diklasifikasikan, relatif tetap, konkrit, teramati, terukur, dan hubungan gejala bersifat sebab akibat.Dalam analisis data guna menguji hipotesis yang telah ditetapkan menggunakan statistik karena bersifat kuantitatif karena data penelitiannya berupa angka-angka.

Peneliti menggunakan metode penelitian eksperimen semu (quasi experimental

design). Sugiyono (2016: 77) menjelaskan ekperimen semu (quasi experimental design) merupakan desain yang mempunyai kelompok-kelompok kontrol, tetapi tidak dapat berfungsi sepenuhnya untuk mengontrol variabel-variabel luar yang mempengaruhi pelaksanaan eksperimen.Quasi experimental design terdiri dari dua bentuk yaitu time series design dan non equivalent control group design.

\section{Tempat, Kegiatan dan Jadwal Penelitian}

\section{Tempat Penelitian}

Penelitian ini dilakukan di SD Negeri 060915 tahun pembelajaran 2018/2019. Alasan peneliti memilih tempat tersebut adalah sebagai berikut.

1. Di SD Negeri 060915 belum pernah dilaksanakan penelitian dengan model pembelajaran kooperatif tipe make a match.

2. Jumlah siswa kelas V SD Negeri 060915 cukup memadai untuk dijadikan subjek penelitian yaitu 60 siswa terdiri dari kelas VA (30 siswa) dan VB (30 siswa).

3. SD Negeri 060915 adalah salah satu sekolah yang strategis serta dekat dengan tempat tinggal peneliti. 
4. Berdasarkan observasi dan data hasil belajar siswa menunjukan bahwa hasil belajar matematika masih rendah.

\section{Kegiatan dan Waktu Penelitian}

Waktu penelitian adalah waktu yang digunakan dalam melaksanakan penelitian.Penelitian ini dilaksanakan pada semester genap tahun pembelajaran 2018/2019 yaitu dari bulan Januari 2019 s/d Juni 2019.

\section{Rancangan/Desain Penelitian}

Jenis desain yang dipilih dalam penelitian ini adalah non-equivalent control group design.Desain penelitian ini terdiri atas dua kelompok yang keduanyatidak ditentukan secara acak, yaitu kelompok eksperimen dan kelompokkontrol.Sebelum kelompok eksperimen diberikan perlakuan (treatment),kedua kelompok tersebut diberikan pratesuntuk mengetahui perbedaankeadaan awal antara kelompok eksperimen dan kelompok kontrol. Hasilpratesyang baik adalah jika nilai kedua kelompok hampir sama atau tidak berbeda secara signifikan. Adapun desain pretest-posttest control grup design menurut Sugiyono (2016: 79) sebagai berikut:

\begin{tabular}{|llr|}
\hline $\mathbf{O}_{1}$ & $\mathrm{X}$ & $\mathbf{O}_{2}$ \\
\hline $\mathbf{O}_{3}$ & & $\mathbf{O}_{4}$ \\
\hline
\end{tabular}

Gambar 2 Desain Eksperimen

Keterangan:

$\mathrm{X}=$ Perlakuan model pembelajaran kooperatif tipe make a match

$\mathrm{O} 1$ =Pre-test sebelum diberi perlakuan pada kelompok eksperimen

$\mathrm{O} 2=$ Post-test setelah diberi perlakuan pada kelompok eksperimen

$\mathrm{O} 3=$ Pre-test pada kelompok kontrol

O4 =Post test pada kelompok kontrol

\section{Populasi dan Teknik Pengambilan Sampel}

\section{Populasi Penelitian}

Sugiyono (2016: 80) menjelaskan populasi adalah wilayah generalisasi yang terdiri atas obyek/subyek yang mempunyai kualitas dan karakteristik tertentu yang ditetapkan oleh peneliti untuk dipelajari dan kemudian ditarik 
kesimpulannya.Sedangkan Arikunto(2017:173), menjelaskan populasi adalah keseluruhan subjek penelitian. Apabila seseorang ingin meneliti semua yang ada dalam wilayah penelitian, maka penelitiannya merupakan penelitian populasi.Studi atau penelitiannya juga disebut studi populasi atau studi sensus. Populasi penelitian ini adalah seluruh siswa kelas V SDNegeri060915 yang berjumlah 60 siswa yang terdiri dari dua kelas yaitu kelasVA yang berjumlah 30siswa dan VB yang berjumlah 30 siswa.

\section{Sampel Penelitian}

Sugiyono (2016:81) mengatakan sampel adalah bagian dari jumlah dan karakteristik yang dimiliki oleh populasi tersebut.Sedangkan Arikunto (2017:174), mengatakansampel adalah sebagian atau wakil populasi yang diteliti. Teknik pengambilan sampel dalam penelitian ini yaitu samplingpurposive.Menurut Sugiyono (2016: 85) sampling purposive yaituteknik penentuan sampel dengan pertimbangan tertentu. Dari populasi 60siswa tersebut, peneliti mengambil sampel kelas VA yang berjumlah 30siswa sebagai kelas eksperimen dan kelas VB berjumlah 30 siswa sebagaikelas kontrol.Pemilihan sampel tersebut berdasarkan pada pertimbangan hasilobservasi dan informasi yang telah diperoleh dari wali kelas. Hasil observasi daninformasidari wali kelas kelas VA pada tanggal 14 Januari 2019 menunjukkan bahwa ketercapaian hasil belajar siswa tergolong rendah daripada kelas VB. Selain itu belum nampak adanya pembelajaran yang menyenangkan sehingga siswa menjadi lebih pasif. Berdasarkan pertimbangan tersebut maka peneliti menentukan sampel kelas VA sebagai kelas eksperimen.

\section{Jenis dan Sumber Data}

\section{Jenis Data}

Adapun data yang yang digunakan dalam penelitian ini adalah kuantitatif.Arikunto (2017: 161) mengatakan bahwa penelitin yang mengolah data dengan metode statistik, maka datanya harus berupa data kuantitatif, yaitu berupa angka-angka.Dalam hal ini data kuantitatif yang diperlukan adalah hasil tes.

\section{Sumber Data}


Menurut Arikunto (2017: 172) yang dimaksud dengan sumber data dalam penelitian adalah subjek dari mana data dapat diperoleh. Dalam penelitian ini penulis menggunakan dua sumber data yaitu:

1. Sumber data primer, Sugiyono (2016: 225) menjelaskan bahwa sumber data primer yaitu sumber data yang langsung memberikan data kepada pengumpul data. Adapun yang menjadi sumber data primer dalam penelitian ini adalah guru dan siswa di SD Negeri 060915 Jl. TB Simatupang Kecamatan Medan Sunggal.

2. Sumber data sekunder, Sugiyono (2016: 225) menjelaskan bahwa sumber data sekunder yaitu sumber yang tidak langsung memberikan data kepada pengumpul data misalnya lewat orang lain atau dokumen. Dalam penelitian ini, dokumentasi dan tes merupakan sumber data sekunder.

\section{Teknikdan Alat Pengumpulan Data}

Pengumpulan data digunakan untuk mendapatkan data yang diperlukan sesuai teknik atau metode yang tepat.Teknik pengumpulan data yang digunakan dalam penelitian ini yaitu:

\section{Observasi}

Observasi sebagai teknik pengumpulan data digunakan untuk mengetahui kondisi sementara akan hal yang akan diteliti dan diamati. Sutrisno Hadi dalam Sugiyono (2016: 145) mengemukakan bahwa, observasi merupakan suatu prosesyang kompleks, suatu proses yang tersusun dari pelbagai proses biologis dan psikologis. Proses yang terpenting dalam tahap observasi adalah pengamatan dan ingatan. Peneliti menggunakan teknik observasi ini untuk mengamati keadaan sekolah yang akan diteliti.

\section{Dokumentasi}

Arikunto (2017: 274) menjelaskan dokumentasi adalah mencari data mengenai hal-hal atau variabel yang berupa catatan, transkip, buku, surat kabar, majalah, prasasti,notulen rapat, lengger, agenda, dan sebagainya. Teknikini digunakan untuk mengetahui nilai hasil belajar siswa dan memperolehgambar atau foto peristiwa saat kegiatan penelitian berlangsung danuntuk mendapatkan data empiris lainnya. 


\section{Tes}

Arikunto (2017:193), menjelaskan tes adalah serentetan pertanyaan atau latihan serta alat lain yang digunakan untuk mengukur keterampilan, pengetahuan, intelegensi, kemampuan atau bakat yang dimiliki oleh individu atau kelompok. Teknik inidigunakan untuk mengukur kemampuan siswa dalam menguasai materipelajaran tertentu.Tes yang digunakan untuk mendapatkan datakuantitatif berupa hasil belajar kognitif siswa.Bentuk tes yang diberikan berupa soal pilihan ganda dengan jumlah 15 butir soal, setiap jawaban benar memiliki skor 1 danjawaban salah memiliki skor 0.Tes diberikan kepada kedua kelas yaitukelas kontrol dan kelas eksperimen yang berupa pratesdan postes.

Suatu tes dapat dikatakan baik jika soal-soal yang terkandung dalam butir tes tersebut dapat mewakili isi materi pembelajaran yang akan diukur. Oleh sebab itu diperlukan penyusunan kisi-kisi instrumen soal yang dapat dijadikan pedoman untuk menulis soal atau merakit soal menjadi tes.

\section{Uji Validitas dan Reliabilitas}

Setelah instrumen tes tersusun, kemudian diuji cobakan kepada kelas yang bukan subjek penelitian.Tes uji coba ini dilakukan untuk mendapatkan persyaratan tes yaitu validitas dan reliabilitas.Setelah diadakan uji coba instrumen, selanjutnya yaitu menganalisis hasil uji coba instrumen.

\section{Uji Validitas}

Arikunto (2017: 211) menjelaskan bahwa sebuah instrumen dikatakan valid apabila mampu mengukur apa yang dinginkan dan dapat mengungkapkan data dari variabel yang diteliti secara tepat. Setelah diuji coba, untuk mengukur tingkat validitas soal, dilakukan dengan teknik korelasi product moment dengan menggunakan SPSS 23 dan dengan rumus:

$r_{x y}=\frac{N \Sigma X Y-\Sigma X \Sigma Y}{\sqrt{\left(N \Sigma \mathrm{X}^{2}-\Sigma \mathrm{X}^{2}\right)\left(N \Sigma \mathrm{Y}^{2}-\Sigma \mathrm{Y}^{2}\right)}}$ (Arikunto,

2017: 213)

Keterangan:

$\mathrm{n}=$ Jumlah responden

$\mathrm{X}=$ Skor variabel (jawaban responden)

$\mathrm{Y}=$ Skor total dari variabel (jawaban responden) 
Kriteria pengujian apabila $r_{\text {hitung }}>r_{\text {tabel }}$ dengan $\alpha=0,05$, maka alat ukur tersebut dinyatakan valid, dan sebaliknya apabila $r_{\text {hitung }}<r_{\text {tabel }}$, maka alat ukur tersebut tidak valid.

\section{Uji Reliabilitas}

Menurut Suharsimi (2017: 221) reliabilitas menunjukan pada suatu pengertian bahwa suatu instrumen cukup dapat dipercaya untuk digunakan sebagai alat pengumpul data karena instrumen tersebut sudah baik.Untuk menghitung reliabilitas soal tes maka digunakan rumus KR20 (Kuder Richardson) sebagai berikut.

$r_{11} \frac{n}{(n-1)}\left\{\frac{S_{t \sum p q}^{2}}{S_{t}^{2}}\right\}$ (Purwanto,

2017: 169)

\section{Keterangan}

$\mathrm{n} \quad$ = jumlah butir

$\mathrm{S}_{\mathrm{t}}^{2}=$ varians total

$\mathrm{p} \quad$ = proporsi soal yang diperoleh

$\mathrm{q}$ = proporsi skor maksimum dikurangi skor yang diperoleh

Koefisien Reliabilitas

\begin{tabular}{|c|c|}
\hline Koefisien Reliabilitas & Tingkat Reliabilitas \\
\hline $0,80-1,00$ & Sangat Kuat \\
\hline $0,60-0,79$ & Kuat \\
\hline $0,40-0,59$ & Sedang \\
\hline $0,20-0,39$ & Rendah \\
\hline $0,00-0,19$ & Sangat Rendah \\
\hline
\end{tabular}

(Sugiyono, 2016: 231)

Tabel 3.5Hasil Uji Reliabilitas

\begin{tabular}{|rr|rr|}
\hline \multicolumn{3}{|c|}{ Reliability Statistics } \\
\hline Cronbach's Alpha & & \multicolumn{2}{|c|}{ N of Items } \\
\hline &, 673 & & \\
\hline
\end{tabular}

Hasil perhitungan uji reliabilitas instrument soal dengan menggunakan SPSS 23uji reliabilitas soal matematika siswa dilakukan dengan rumus alpha. Hasil perhitungan diperoleh indeks reliabilitas instrument sebesar 0,673. Dari 
hasil perhitungan data tersebut dapat disimpulkan bahwa tingkat reliabilitasnya kuat.

\section{Teknik Pengolahaan/Analisis Data}

Data yang dianalisis dalam penelitian ini adalah data kuantitatif, yaitu nilai kemampuan akhir yang diperoleh dari nilai postes. Setelah melakukan perlakuan terhadap kelas eksperimen dan kelas kontrol maka diperoleh data berupa hasil prates dan postes. Adapun langkah-langkah analisis data sebagai berikut.

1. Menyusun nilai prates dan postes dalam bentuk tabel.

2. Menghitung nilai rata-rata (mean), standar deviasi, dan standar eror dari data postes.

a. Mencari nilai rata-rata (mean) dengan rumus:

$$
\begin{aligned}
& \mathrm{M}_{\mathrm{x}}=\frac{\sum f x}{n} \quad \ldots \ldots \ldots \ldots \ldots \ldots \ldots \ldots \ldots \ldots \ldots \ldots \ldots \ldots \ldots \ldots \ldots \ldots \ldots \ldots \ldots \\
& \text { 2014: } 85) \\
& \text { Keterangan : } \\
& \mathrm{M}_{\mathrm{x}} \quad \text { =Rata-rata } \\
& \quad \sum f x \quad=\text { Jumlah dari hasil perkalian antara midpoint dari masing- } \\
& \quad \text { masing interval, dengan frekuensi } \\
& \mathrm{n}=\text { Jumlah sampel }
\end{aligned}
$$

b. Mencari standar deviasi dengan rumus:

$$
\mathrm{SD}=\sqrt{\frac{\sum f X^{2}}{n}}
$$

Keterangan:

$\mathrm{SD}=$ Deviasi Standar

$\sum f X^{2}=$ Jumlah hasil perkalian antara frekuensi masing-masing skor, dengan deviasi skor yang telah dikuadratkan

$\mathrm{n} \quad=$ Jumlah sampel

c. Menghitung standar eror dari variabel hasil postes dengan menggunakan rumus:

$$
\mathrm{SE}_{\mathrm{M}}=\frac{S D}{\sqrt{N-1}}
$$

2014: 282) 
Keterangan:

$\mathrm{SE}_{\mathrm{M}}=$ Standar Eror

$S D \quad=$ Standar Deviasi

$N \quad=$ Jumlah sampel

$1=$ Bilangan konstan

3. Menggambarkan nilai rata-rata prates dan postes dalam diagram batang.

\section{Uji Normalitas}

Uji normalitas dimaksudkan untuk memperlihatkan bahwa data sampel berasal dari populasi yang berdistribusi normal. Ada beberapa cara yang digunakan untuk menguji normalitas data, antara lain: dengan kertas peluang normal, uji Chi Kuadrat, uji Liliefors, dengan teknik Kolmogorov-Smirnov, Shapiro-Wilk dan dengan SPSS. Peneliti menggunakan rumus KolmogorovSmirnovdengan bantuan program SPSS 23 untuk pengujian normalitas data. Uji normalitas dengan menggunakan bantuan program SPSSmenghasilkan 4 jenis keluaran yaitu Processing Summary, Descriptives, Test Of Normality, dan $Q-Q$ plots. Keluaran yangdigunakan dari proses penghitungan ialah Test of Normality.Pengambilan keputusan dari uji normalitas adalah:

Jika Sig. > 0,05 maka data berdistribusi normal.

Jika Sig. $<0,05$ maka data tidak berdistribusi normal.

\section{Uji Homogenitas}

Uji homogenitas dimaksudkan untuk memperlihatkan bahwa kedua atau lebih kelompok data sampel berasal dari populasi yang memiliki variansi sama. Uji homogenitas dalam penelitian ini menggunakan rumus Levene Statistic dengan program SPSS 23. Untuk keperluan penelitian hanya keluaran Test OfHomogenity Of Varience yang digunakan, sementara keluaran data yang lain tidak digunakan. Selanjutnya data keluaran tersebut ditafsirkan dengan memilih salah satu statistik, yaitu statistik yang didasarkan pada rata-rata (Based of Mean).Pengambilan keputusan dari uji homogenitas adalah jika Sig. >0,05 maka variansi pada tiap kelompok sama (homogen), jika Sig. $<0,05$ maka variansi pada tiap kelompok tidak sama (tidak homogen). 


\section{Uji Hipotesis}

Untuk pengujian hipotesis peneliti menggunakan Uji regresi linier sederhana dan uji t (Independent Sampel t-test)dalam Program Statistik SPSS 23.Uji regresi linier digunakan untuk mengetahui ada tidaknya pengaruh antar variabel, apabila ada seberapa eratnya pengaruh serta berarti atau tidaknya pengaruh itu sedangkan Independent Sampel t-test digunakan untuk menguji perbedaan rata-rata dari dua kelompok dataatau sampel yang independen.Berikut peneliti sajikan perhitungan ujihipotesis dalam penelitian ini.

Ha: Ada pengaruh yang positif dan signifikan pada penerapan model pembelajaran kooperatif tipe make a match terhadap hasil belajar matematika siswa kelas V SD Negeri 060915 J1 TB Simatupang Kecamatan Medan Sunggal TahunPembelajaran 2018/2019.

Ho:Tidak ada pengaruh yang positif dan signifikan pada penerapan model pembelajaran kooperatif tipe make a match terhadap hasil belajar matematika siswa kelas V SD Negeri 060915 Jl. TB Simatupang Kecamatan Medan Sunggal Tahun Pembelajaran 2018/2019.

Berdasarkan rumus diatas, ditetapkan taraf signifikansi 5\% atau $\alpha=0,05$ maka kaidah keputusan yaitu: jika $r_{\text {hitung }}<r_{\text {tabel }}$, maka Ha ditolak, sedangkan jika $r_{\text {hitung }}>r_{\text {tabel }}$ maka Ha diterima. Apabila Ha diterima berarti ada pengaruh yang positif dan signifikan pada penerapan model pembelajaran kooperatif tipe make a match terhadap hasil belajar matematika siswa kelas V SD Negeri 060915 J1 TB Simatupang Kecamatan Medan Sunggal tahun pelajaran 2018/2019.

\section{Prosedur Penelitian}

1. Tahap Persiapan

a. Observasi ke sekolah yang akan digunakan untuk penelitian

b. Peneliti meminta surat permohonan izin penelitian dari Fakultas.

c. Mengajukan surat permohonan izin penelitian ke SD Negeri 060915 untuk mengadakan penelitian di sekolah tersebut. 
d. Berkonsultasi dengan kepala sekolah dan guru bidang studi matematika dalam rangka observasi untuk mengetahui aktivitas dan kondisi dari lokasi atau objek penelitian.

e. Mengajukan instrumen penelitian, yaitu tes hasil belajar matematika siswa.

f. Peneliti melakukan uji validitas dan reliabilitas instrumen penelitian dengan validator ahli, yaitu dengan bantuan dosen-dosen dan guru-guru yang memiliki pengetahuan tentang tes tersebut.

2. Tahap Pelaksanaan

a. Menguji coba instrumen pengumpul data (tes) kepada siswa kelas V yang bukan subjek penelitian.

b. Menganalisis data hasil uji coba instrumen untuk memperoleh instrumen yang telah valid dan reliabel.

c. Memberikan pratespada kedua kelompok.

d. Melakukan perlakuan pada kelas eksperimen dalam hal ini dengan menerapkan model pembelajaran kooperatif tipe make a match dan tidak memberikan perlakuan berupa model pembelajaran kooperatif tipe make a match terhadap kelas kontrol.

e. Memberikan postespada kedua kelompok.

\section{Tahap Analisis}

Dalam tahap ini, peneliti menghitung hasil pratesdan postesyang diperoleh pada masing-masing kelas eksperimen dan kontrol sesuai teknik analisis data yang digunakan oleh peneliti.

\section{Tahap Kesimpulan}

Kesimpulan didapat setelah mengetahui hasil interpretasi data tersebut akhirnya dapat disimpulkan apakah ada pengaruh model pembelajaran kooperatif tipe make a match terhadap hasil belajar matematika.

\section{HASIL PENELITIAN DAN PEMBAHASAN}

Pembahasan Hasil Temuan 
Penelitian ini dilakukan dikelas V SD Negeri 060915, pada dua kelas yang dilakukan perlakuan yang berbeda dimana kelas eksperimen dengan menggunakan model pembelajaran kooperatif tipemake a match sedangkan dikelas kontrol tidak menggunakan model pembelajaran. Kedua kelas menggunakan materi yang sama yaitu penjumlahan dan pengurangan pecahan biasa dan campuran.

Untuk mengetahui kemampuan awal siswa, peneliti melaksanakan prates dikelas eksperimen dan kelas kontrol, dengan jumlah soal 15 butir dan jenis soal yang sama yaitu pilihan berganda. Di kelas eksperimen diperoleh nilai rata-rata prates 31,76 dan dikelas kontrol diperoleh nilai rata-rata prates 38,03.

Selanjutnya penelitimelakukan perlakuan yaitu mengajarkan materi pelajaran di kelas eksperimen dengan menggunakan model pembelajaran kooperatif tipe make a match, dan di kelas kontrol peneliti mengajarkan materi pelajaran tidak dengan menggunakan model pembelajaran. Setelah mengajarkan materi pelajaran peneliti kembali memberikan postes untuk mengukur sejauh mana pemahaman siswa tentang materi yang diajarkan, dan hasil yang didapatkan dari nilai rata-rata postes di kelas eksperimen dengan menggunakan model pembelajaran kooperatif tipe make a match adalah 75,33 dan nilai rata-rata postes di kelas kontrol adalah 58,9.

Hasil uji normalitas untuk data hasil belajar kelas eksperimen yang menggunakan model pembelajaran kooperatif tipe make a match menunjukkan nilai signifikan sebesar 0,057 danuntuk kelas kontrol sebesar 0,200. Hasil pengujian tersebut menunjukkanbahwa data berdistribusi normal.Pada pengujian homogenitas datanilai signifikansi yang diperolehsebesar 0,076>0,05. Hasil pengujian tersebut menunjukan bahwa data homogen.

Untuk uji hipotesis, dalam penelitian ini menggunakan uji t. Hasil dari uji t yang telah dilakukan yaitu data mempunyai varian yang sama. Hal tersebut dapat dilihat dari nilai signifikan lebih besar dari 0,05 yaitu 0,076. Sedangkan nilai Sig (2-tailed) sebesar 0,038 yang berarti sig (2-tailed) $<0,05$, maka Ho ditolak dan Ha diterima.Artinya ada pengaruh model pembelajaran model pembelajaran 
kooperatif tipe make a match terhadap hasil belajar matematika pada materi penjumlahan dan pengurangan pecahan biasa dan pecahan campuran.

Untuk mengetahui seberapa besar pengaruh model pembelajaran kooperatif tipe make match terhadap hasil belajar matematika maka digunakan uji analisis regresi linier sederhana. Hasil yang diperoleh nilai koefisien korelasi $\mathrm{R}$ sebesar 0,591.Hal ini menjelaskan bahwa hubungan antara variabel bebas (X) model pembelajaran kooperatif tipe make a match terhadap variabel terikat (Y) hasil belajar matematika siswa adalah sedang. Selanjutnya koefisien determinasi RSquarre sebesar 0,349. Hal ini menunjukan bahwa pengaruh model pembelajaran kooperatif tipe make a match terhadap hasil belajar matematika siswa kelas V SD Negeri 060915 adalah sebesar 34,9\% sedangkan sisanya sebesar $65,1 \%$ dipengaruhi variabel lain yang tidak diteliti oleh peneliti dalam menentukan nilai hasil belajar matematika pada penelitian ini.

Berdasarkan hasil data yang diperoleh dari penelitian di SD Negeri 060915 dapat dikatakan bahwa pembelajaran dengan menggunakan model pembelajaran kooperatif tipe make a match membuat siswa lebih termotivasi, dan aktifserta lebih memahami materi penjumlahan dan pengurangan pecahan biasa dan campuran. Siswa tidak menutup diri untuk mengerjakan soal ke depan kelas dan memperaktekan penggunaan alat peraga yang disediakan guru, tidak malu bertanya dan menjawab pertanyaan yang diberikan guru.

Berdasarkan penelitian di SD Negeri 060915 dan hasil yang diperoleh dari data penelitian, penulis menyimpulkan bahwa ada pengaruh yang signifikan pada penerapan model pembelajaran koopertif tipe make a match terhadap hasil belajar matematika siswa kelas $\mathrm{V}$ pada materi penjumlahan dan pengurangan pecahan biasa dan campuran.

\section{PENUTUP}

\section{Simpulan}

Berdasarkan hasil pengolahan data penelitian yang diperoleh,maka dapat ditarik kesimpulan sebagai berikut:

1. Nilai rata-rata hasil belajar matematika siswa pada kelas eksperimen dengan menggunakan model pembelajaran kooperatif tipe make a match pada materi penjumlahan dan pengurangan pecahan biasa dan pecahan campuran 
adalah75,33.Nilai dengan predikatsangat baik sebanyak 17 siswa yaitu 56,66\%, predikat cukup sebanyak 5 siswa yaitu $16,66 \%$, predikat kurang sebanyak 4 siswa yaitu 13,33\%, predikat gagal sebanyak 4 siswa 13,33\%.

2. Nilai rata-rata hasil belajar matematika siswa pada kelas kontrol tanpa menggunakan model pembelajaran pada materi penjumlahan dan pengurangan pecahan biasa dan pecahan campuran adalah 58,9. Nilai dengan predikatsangat baik sebanyak 10 siswa yaitu 33,33\%, predikat baik sebanyak 2 siswa yaitu $6,66 \%$, predikat cukup sebanyak 2 siswa yaitu 6,66\%, predikat kurang sebanyak 3 siswa yaitu 10\%, predikat gagal sebanyak 13 siswa yaitu 43,33\%.

3. Dari hasil penelitian diatas dapat disimpulkan bahwa ada pengaruh yang positif dan signifikan pada penerapan model pembelajaran kooperatif tipe make a match terhadap hasil belajar matematika siswa kelas V SD Negeri 060915. Berdasarkan analisis uji $t$ dengan ketentuan nilai $t_{\text {hitung }}>t_{\text {tabel }}$ dimana $t_{\text {tabel }}$ pada taraf signifikan 5\%. Dengan ini diperoleh hasil perhitungan uji hipotesis yaitu nilai signifikan (2-tailed) 0,038 artinya 0,038<0,05 sehingga Ho ditolak dan $\mathrm{Ha}$ diterima. Untuk mengetahui seberapa besar pengaruh model pembelajaran kooperatif tipe make match terhadap hasil belajar matematika maka digunakan uji analisis regresi linier. Hasil yang diperoleh nilai koefisien korelasi $\mathrm{R}$ sebesar 0,591. Hal ini menunjukan bahwa hubungan model pembelajaran kooperatif tipe make a match terhadap hasil belajar matematika siswa kelas V SD Negeri 060915 adalah sedang. Selanjutnya besarnya pengaruh model pembelajarankooperatif tipe make a match adalah 34,9\% sisanya sebesar $65,1 \%$ dipengaruhi faktor-faktor lain yang tidak diteliti dalam menentukan nilai hasil belajar matematika pada penelitian ini.

\section{Saran}

Berdasarkan kesimpulan dan implikasi penelitian ini maka peneliti dapat memberikan beberapa saran sebagai berikut.

1. Bagi Guru

a. Penerapan model pembelajaran koopertif tipe make a match berpengaruh positif terhadap hasil belajar matematika dan dapat meningkatkan hasil belajar matematika namun pengaruh yang diberikan hanya34,9\% sehinggaguru tidak 
harus menggunakan model pembelajaran kooperatif tipe make a match dalam proses belajar mengajar pelajaran matematika tetapi guru dapat memilih model pembelajaran yang lain sesuai dengan materi yang akan dibawakan saat proses pembelajaran agar dapat membuat siswa lebih aktif dan kreatif sehingga hasil belajar matematika dapat meningkat dengan baik.

b. Pembelajaran harus dilakukan dengan model pembelajaran yang bervariasi agar tercipta proses belajar yang menyenangkan.

c. Selain menggunakan model pembelajaran, guru hendaknya menggunakan sumber-sumber belajar yang bervariasi dan menarik perhatian siswa.

2. Bagi Sekolah

a. Sekolah hendaknya menyediakan fasilitas sekolah dengan lebih lengkap untuk mendorong dan meningkatkan cara belajar yang baik untuk siswa maupun guru.

a. Sekolah perlu melakukan penelitian lebih lanjut mengenai model pembelajaran kooperatif tipe make a match disekolah. Hal ini dapat membantu pihak sekolah untuk meningkatkan dan mengetahui hasil belajar.

3. Bagi Peneliti Selanjutnya

Hasil penelitian dapat dijadikan sebagai acuan untuk menambah pengetahuan dan wawasan bagi rekan peneliti lain dalam penelitian selanjutnya yang mengambil topik yang sama yaitu tentang pengaruh model pembelajaran kooperatif tipe make a match pada mata pelajaran matematika.

\section{DAFTAR PUSTAKA}

Aqib, dkk. 2016. Penelitian Tindakan Kelas. Bandung: YramaWidya.

Amri, Sofan. 2016. Pengembangan \& Model Pembelajaran dalam Kurikulum 2013. Jakarta: Prestasi Pustaka.

Arikunto, Suharsimi. 2010. Metode Penelitian Pendidikan. Bandung: Alfa Beta.

. 2017. Prosedur Penelitian Suatu Pendekatan Praktik. Jakarta: PT Rineka Cipta.

Depdiknas. 2015. Undang-Undang No 20 Tahun 2003 tentang SISDIKNAS \& Peraturan Pemerintah RI Tahun 2015 Tentang Standar Nasional Pendidikan Serta Wajib Belajar. Bandung: Citra Umbara. 
Hamzah, Ali dan Muhlisrarini. 2016. Perencanaan dan Strategi Pembelajaran Matematika. Jakarta: PT Rajagrafindo Persada.

Hendriana, Heris dan Utari Soemarmo. 2016. Penilaian Pembelajaran Matematika. Bandung: PT Refika Aditama.

Herman. 2016. Pengembangan Kurikulum dan Pembelajaran Matematika. Malang: UM Press.

Heruman. 2017. Model Pembelajaran Matematika. Bandung: PT Remaja Rosdakarya.

Huda, Miftahul.2017. Model- Model Pengajaran dan Pembelajaran. Yoyakarta:Pustaka Pelajar.

Isjoni. 2014. Cooperative Learning: Efektivitas Pembelajaran Kelompok. Bandung: Alfabeta.

Istarani. 2015. 58 Model Pembelajaran Inovatif. Medan: Media Persada.

Istirani dan Pulungan Intan. 2017. Ensiklopedia Pendidikan. Medan: Media Persada.

Kurniasih, Imas dan Berlin Sani). 2016. Ragam Pengembangan Model Pembelajaran Untuk Meningkatkan Profesioanal Guru. Kata Pena.

Noor, Juliansyah. 2015. Metodologi Penelitian. Jakarta: Prenamedia Group.

Purwanto. 2017. Evaluasi Hasil Belajar. Yogyakarta: Pustaka Belajar

Rahmawati, Shanti Eka. 2017. Pengaruh Model Pembelajaran Kooperatif Tipe Make A Match Terhadap Hasil Belajar IPS Siswa Kelas IV SD Negeri 6 Metro Barat. (online) Dalam URL:http://digilib.unila.ac.id/27728/3/SKRIPSI\%20TANPA\%20BAB\% 20PEMBAHASAN.pdf (diakses pada 22 Januari 2019, pukul 14.00 WIB).

Rasyidin, Al dan Wahyuddin Nur Nasution. 2015. Teori Belajar dan Pembelajaran. Medan: Perdana.

Riantika, Feti. 2016. Pengaruh Model Cooperative Learning Tipe Make A Match Terhadap Hasil Belajar Matematika Siswa Kelas V SDN 2 Metro Selatan.(online)

URL:http://digilib.unila.ac.id/23875/3/SKRIPSI\%20TANPA\%20BAB\% 20PEMBAHASAN.pdf (diakses pada 22 Januari 2019, pukul 14.00 WIB).

Rusman. 2013. Belajar dan Pembelajaran Berbasis Komputer. Bandung: Alfabeta.

. 2017. Model-Model Pembelajaran. Jakarta: PT Raja Grafindo Persada. 
Sudjana. 2017. Metode Statiska. Bandung: Tarsito.

Sumiati dan Asra. 2013. Metode Pembelajaran. Bandung: CV Wacana Prima.

Sugiyono, 2016. Metode Penelitian Kuantitatif, Kualitatif dan R\&D. Bandung: Penerbit Alfabeta.

Suprijono, Agus. 2015. Cooperative Learning:Teori dan Aplikasi PAIKEM. Yogyakarta: Pustaka Pelajar.

Suyono dan Hariyanto. 2016. Belajar dan Pembelajaran. Bandung: PT Remaja Rosdakarya.

Syah, Muhibbin. 2015. Psikologi Pendidikan. Bandung: PT Remaja Rosdakarya.

. 2018. Psikologi Belajar. Bandung: Alfabeta. 